University of Nebraska - Lincoln

DigitalCommons@University of Nebraska - Lincoln

1988

Foraging Ecology of the Bee Habropoda laboriosa (Hymenoptera: Anthophoridae), an Oligolege of Blueberries (Ericaceae: Vaccinium) in the Southeastern United States

James H. Cane Department of Entomology, Alabama Agricultural Experiment Station, Auburn University, Auburn, Ala. 36849

Jerry A. Payne

USDA, Southeastern Fruit and Tree Nut Research Laboratory, Byron, Ga. 31008

Follow this and additional works at: https://digitalcommons.unl.edu/entomologyother

Part of the Entomology Commons

Cane, James H. and Payne, Jerry A., "Foraging Ecology of the Bee Habropoda laboriosa (Hymenoptera: Anthophoridae), an Oligolege of Blueberries (Ericaceae: Vaccinium) in the Southeastern United States" (1988). Entomology Papers from Other Sources. 75.

https://digitalcommons.unl.edu/entomologyother/75

This Article is brought to you for free and open access by the Entomology Collections, Miscellaneous at DigitalCommons@University of Nebraska - Lincoln. It has been accepted for inclusion in Entomology Papers from Other Sources by an authorized administrator of DigitalCommons@University of Nebraska - Lincoln. 


\title{
Foraging Ecology of the Bee Habropoda laboriosa (Hymenoptera: Anthophoridae), an Oligolege of Blueberries (Ericaceae: Vaccinium) in the Southeastern United States ${ }^{1}$
}

\author{
JAMES H. CANE ${ }^{2}$ AND JERRY A. PAYNE 3
}

\begin{abstract}
Ann. Entomol. Soc. Am. 81(3): 419-427 (1988)
ABSTRACT The anthophorid bee, Habropoda (=Emphoropsis [R. W. Brooks, personal communication]) laboriosa (F.), is a locally abundant, vernal, univoltine species. It flies from February through April in Georgia and Alabama. In these states, females are oligolectic on Vaccinium spp., particularly V. ashei Reade and V. corymbosum L., with Gelsemium sempervirens (L.), Quercus alba L., and Cercis canadensis L. as minor, alternate pollen hosts. Pollen-harvesting female $H$. laboriosa sonicate $V$. ashei flowers to release pollen, averaging 5.7 buzzes during their average 2.6-s floral visit, which is a handling rate 3 times faster than coforaging Bombus spp. Furthermore, mean floral handling rates of $H$. laboriosa females at $V$. ashe $i$ are individually more uniform than those of coforaging, polylectic Bombus spp., a hitherto undemonstrated but expected evolutionary outcome of oligolecty. Sonicated pollen accumulates on a ventral cephalic "safe site" of both sexes, which is the common site of $V$. ashei stigmatic contact. Floral probes are strictly legitimate (no robbing). Based upon its relative abundance at Vaccinium spp., phenology, floral handling behaviors and rates, and pollen preferences in the southeastern United States, we conclude that $H$. laboriosa is an oligolege adapted to species of Vaccinium for its pollen and nectar resources.
\end{abstract}

KEY WORDS Insecta, Habropoda, Vaccinium, pollination

THE HOLARCTIC ANTHOPHORID genus Habropoda Smith (including Emphoropsis Ashmead) (R. W. Brooks, personal communication) is represented in the United States by 21 species (Krombein et al. 1979). Only one species, H. laboriosa (F.), occurs east of the Mississippi River. It extends from New Jersey and Illinois south to Mississippi and Florida (Mitchell 1962) (with H. l. fedorensis Cockerell reported from Texas, Krombein et al. 1979).

Floral associations and phenologies of nearctic Habropoda are known only for $H$. miserabilis (Cresson) (Stephen \& Torchio 1961, Uno 1982, Gordon 1984) and $H$. pallida (Timberlake) (Bohart et al. 1972). The pollen provisions of $H$. pallida suggest that it is a Larrea oligolege (Hurd \& Linsley 1975). Nest provisions of $H$. miserabilis consist of the pollens of Abronia, Convolvulus, and Lupinus (and that of Raphanus [R. W. Brooks, personal communication]). In a pollination study, Uno (1982) reported that $H$. miserabilis (in error as mirabilis) can be the common nectarivore at Iris douglasiana Herbert.

Floral associations of other Habropoda spp. are largely unknown. Krombein et al. (1979) list diverse nectar plants for some nearctic Habropoda species. A few female $H$. rugosissima Cockerell were noted by Linsley et al. (1963) to collect pollen

This article reports the results of research only. Mention of a proprietary product does not constitute an endorsement or a recommendation for its use by USDA.

2 Department of Entomology, Alabama Agricultural Experiment Station, Auburn University, Auburn, Ala. 36849.

USDA, Southeastern Fruit and Tree Nut Research Laboratory, Byron, Ga. 31008 from desert Oenothera and Stanleya. Cockerell (1934) observed female $H$. birkmanni Cockerell gathering pollen from Lupinus and Aesculus, and H. depressa (Fowler) has been noted to gather oak pollen (Fowler 1899).

In North Carolina, Ornduff (1970) noted H. laboriosa visiting Gelsemium sempervirens (L.), and Garcia (1981) observed females visiting Vaccinium ashei Reade. Little else is reported for foraging biologies of other Habropoda spp.

The objectives of this study are to document the phenologies and abundances of foraging $H$. laboriosa in central Alabama and Georgia, establish its pollen preferences and foraging ethology, and relate these to its congeners; and to compare aspects of its foraging efficiency with polylectic members of its pollen-foraging guild at $V$. ashei, as a contribution to our understanding of oligolecty in bees.

\section{Materials and Methods}

From February through April during 1985 and 1986, we observed and sampled $H$. laboriosa at coastal plain and piedmont sites in Jefferson County, Fla.; Charlton, Monroe, and Peach counties, Ga.; and Lee, Clay, and Baldwin counties, Ala. All sites adjoined hardwood or mixed hardwood-pine forests that contained native Vaccinium species. Our preliminary fieldwork showed that $H$. laboriosa frequented Vaccinium spp. for pollen, so our detailed observations and experiments were performed at the following four sites: a 0.7 -ha planting of V.ashei, $2.4 \mathrm{~km} \mathrm{~S}$ of Bolingbroke, Monroe Coun- 
ty, Ga.; a small $\left(100 \mathrm{~m}^{2}\right)$ plot of cultivated V. ashei in a hardwood forest clearing, $8 \mathrm{~km} \mathrm{E}$ of Fort Valley, Peach County, Ga.; a 0.5-ha planting of $V$. ashei $3 \mathrm{~km} \mathrm{~S}$ of Auburn, Lee County, Ala.; and two small research plantings of $V$. ashei in open fields at Auburn University, Auburn, Lee County, Ala. We logged $>200$ person-hours of observations at the four sites.

Our field notes and experimentation were supplemented by $35-\mathrm{mm}$ photographs and sound recordings using a modified Marantz PMD 200 cassette recorder with a high-gain preamplifier and Sennheiser ME88 spot head microphone. Floral handling sounds of pollen-foraging female $H$. laboriosa and four species of Bombus queens ( $B$. bimaculatus Cresson, B. fraternus (Smith), B. griseocollis (Degeer), and B. impatiens Cresson, not readily distinguished in flight) (Cane 1987), and mostly nectarivorous Apis mellifera L. and Xylocopa virginica (L.), were tape-recorded as they visited series of $V$. ashei flowers. Using a 10-channel timer program for the IBM Portable PC microcomputer, recorded foraging bouts were transcribed using slow playback (accurate to $1 / 20 \mathrm{~s}$ ). Mean floral handling durations and interfloral travel rates of the four genera, and the number of buzzes per flower by Bombus spp. and $H$. laboriosa (after square root transformation), were compared by nested analysis of variance (ANOVA) (individuals within taxon) using the individual's mean square (MS) as the error term for the species comparisons (SAS Institute 1985), followed by Tukey's studentized range test if appropriate. For visits involving sonication by $H$. laboriosa and Bombus spp. females, we calculated Pearson's product-moment correlation for the number of buzzes versus visit duration. To compare the species-specific or "intrinsic" variation in individual floral handling rates of pollen-foraging Bombus (pooled species) and $H$. laboriosa, the durations of their floral visits were first transformed to $\log _{10}$, thereby eliminating their individual mean differences as constants (Lewontin 1966). Using these transformed data, the ratios of their mean variances were compared to the $F$ distribution.

In an Alabama experiment, we excluded bees from budded $V$. ashei inflorescences with the use of net exclosures. During anthesis, we removed each net bag in early afternoon, timed the visitation bout of a freely foraging bee, and tallied the number of flowers visited to assess the bees' response to accumulated floral rewards. Nearby conspecific bees that visited unmanipulated inflorescences were similarly timed. Data were compared by two-way ANOVA for taxon and for virgin versus unbagged flowers.

Pollen for scopal load analyses was independently sampled from the two hind tibiae of individually collected females. Samples were mounted in gelatin imbued with Alexander's stain and viewed with light microscopy. Two perpendicular 100grain transects were taken from each of the two scopal samples ( $n=400$ grains per bee). Pollen was identified by comparison with floral samples.

Voucher bees are deposited with J.H.C. and in the Snow Entomological Museum, University of Kansas, Lawrence.

\section{Results}

Phenology. In Alabama and Georgia, we collected adult $H$. laboriosa from late February through April, coincident with the local flowering of most species of Vaccinium. From May to January the bee is absent from our monthly collections. Mitchell (1962) reported some Florida populations flying from November to February. Female $H$. laboriosa in the University of Florida collections reflect a continuum of activity from January into April in Winter Park, Gainesville, and Alachua counties, Fla. As early as 20 February in central Alabama and Georgia, we first observed unworn males at Vaccinium elliottii (Chapman). In central Georgia, we last saw males on 15 April.

We first saw females of $H$. laboriosa visiting $V$. ashei and Cercis canadensis $\mathrm{L}$. for nectar during 10-13 March in central Alabama. On 13 March 1986 near Monticello, Fla., females were already gathering pollen at cultivated V. ashei. Near Auburn, we last saw females foraging on 25 April at $V$. ashe $i$, at the end of its flowering season. On milder days (little wind, clear, $>20^{\circ} \mathrm{C}$ ), female $H$. laboriosa foraged at V. ashei from 0730 to 1900 hours CST.

Floral Associations. At every location $(n=12)$ where we encountered $H$. laboriosa, we found them foraging at species of Vaccinium for nectar (also for pollen in the case of females). We collected one or both sexes at Vaccinium ashei, V. atrococcum (Gray) Porter, V. corymbosum L., V. elliottii, V. myrsinites Lamarck, and V. vacillans Torrey. We rarely ( $<1 \%$ total sightings) observed females foraging for nectar $\left(^{*}\right)$ or pollen $(+)$ or both at Prunus umbellata Elliott $(*,+)$, Gelsemium sempervirens $(*,+)$, Quercus alba L. (+), Linaria canadensis L. $\left(^{*}\right)$, and Cercis canadensis $(*,+)$. On some days, we noted the earliest $H$. laboriosa, honey bees, and bumblebees visiting flowers other than Vaccinium (e.g., Prunus), but $H$. laboriosa rarely bore pollen loads while at these plants. Within the hour on such mornings, all $\mathrm{H}$. laboriosa, and some but not all polyleges, then shifted over to Vaccinium, perhaps responding to resource availability. We observed the highest densities of females (812 per plant) at $V$. ashei and $V$. corymbosum.

Because it blooms early, $V$. elliottii attracts abundant males in late February, but on occasions $(n<5)$ we also observed males at Prunus umbellata Elliott, C. canadensis, Lonicera fragrantissima Lindley \& Pax, and ornamental Viola. Also blooming at our sites were Acer rubrum L., Crataegus spp., Vaccinium stamineum L., Ulmus spp., Lamium amplexicaule L., Spiraea spp., Stellaria spp., Brassica spp., Taraxacum officinale Wiggers, 


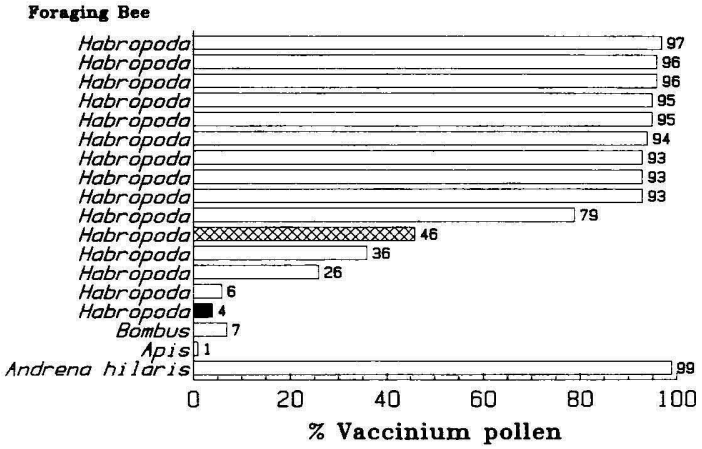

Fig. 1. Proportional representations of pollens in the scopal loads of bees visiting $V$. ashei. Data represent samples of 400 pollen grains per bee. Foraging at $V$. ashei, clear bars; at Gelsemium, solid bar; at Prunus, cross-hatched bar.

and Viola arvensis Murray, but neither sex of $H$. laboriosa was seen at these flowers.

Pollen Resources. The distinctive Vaccinium tetrads typically comprised the pollen loads of female $H$. laboriosa at $V$. ashei, in contrast to the few polylectic bees that we sampled (Fig. 1). Of the $H$. laboriosa females collected at cultivated $V$. ashei at our four study locations in March and April 1985 and 1986, most yielded essentially pure loads of Vaccinium (median load, 94\% Vaccinium grains; range, 6-97\%). Pure Vaccinium loads also characterized one female each collected at $V$. corymbosum and V. elliottii, but three females collected at V. myrsinites in the Okefenokee Swamp (Charlton County, Ga.) had $24 \%$ or less Vaccinium pollen in their scopal loads. A female at G. sempervirens (not shown in Fig. 1) had a $98 \%$ pure scopal load from that floral species. A female at Prunus umbellata bore $46 \%$ Prunus pollen. Only one of 20 sampled $H$. laboriosa bore any asteraceous pollen, which constituted $19 \%$ of her load. Pine pollen was counted in three-fourths of the bee samples but was a minor constituent (up to $2 \%$ of the total grains).

Pollen pellets ( $n=15$ ) sampled from a honey bee colony bordering the Bolingbroke planting yielded no Vaccinium grains. Pollen of Vaccinium made up an estimated $93 \%$ (7\% oak pollen) of the provision mass of the single $H$. laboriosa nest we found in dry (4\% moisture), sandy soil ( $85 \%$ sand by weight) adjoining the south Auburn site.

Female $H$. laboriosa gathered redbud pollen only early in the season, while oak pollen was collected later when blueberry flowers were rare because of frost or late-season senescence. At G. sempervirens, pollen foraging was seen only sporadically (despite hours of searching) at the Fort Valley site, primarily on hot, dry afternoons.

Seven female $H$. laboriosa in the University of Florida collections bore pollen loads from Lupinus (L. angustifolius L. and L. cumulicola Small), but the remaining 95 females lacked pollen loads (and were not collected at Vaccinium). All 42 males and

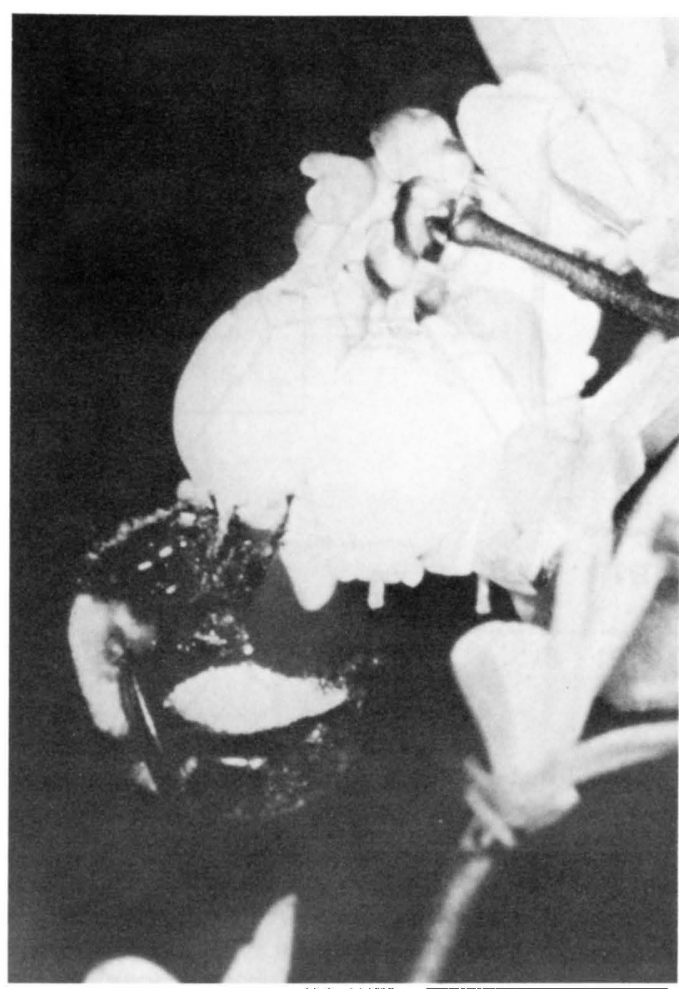

Fig. 2. Female H. laboriosa foraging for pollen and nectar at $V$. ashei. Note the pendant flowers and her inverted position.

24 females in the University of California (Berkeley) collections were taken at redbud, but none of them bore a pollen load. Three females from the University of Kansas collections bore pollen loads. One (from St. Augustine, Fla.) bore Cirsium pollen; the other two (from Hattiesburg, Miss.) bore Gelsemium and several unknown pollens.

Foraging Behavior at Vaccinium. Both sexes of $H$. laboriosa always ( $>3,000$ visits observed) foraged legitimately for nectar at $V$. ashei by probing through the terminal orifice of the corolla. However, robber slits pierced near the base of the corolla by $X$. virginica were often abundant $(35 \%$ of all corollas at Bolingbroke planting, $n=125$ ). Polylectic honey bees and carpenter bees (but not Bombus spp.) readily, and sometimes exclusively, probed the flowers illegitimately through these robber slits ( $96 \%$ of 130 honey bees at the site south of Auburn on 26 March). On 12 occasions, we observed honey bees cutting new slits with their fore tarsi.

Female H. laboriosa work Vaccinium flowers from an inverted position, gripping the probed flower with their prothoracic (and sometimes mesothoracic) legs (Fig. 2). Middle (and sometimes hind) legs may grip an adjacent flower or leaf instead. Alternatively, the hind legs are held at the sides during the floral visit.

To release pollen from the poricidally dehiscent anthers of Vaccinium, female $H$. laboriosa and 


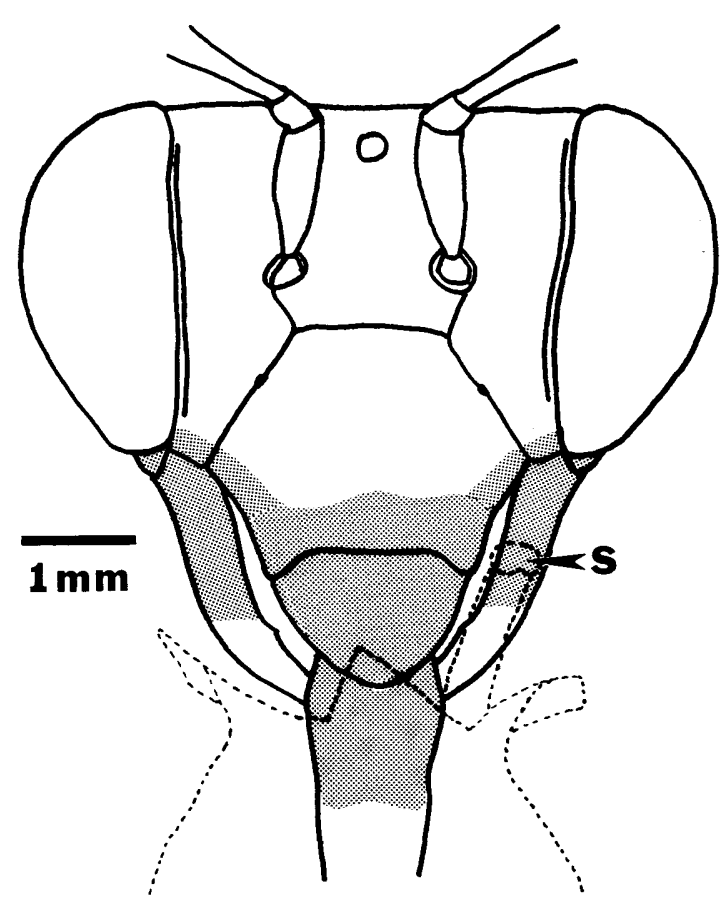

Fig. 3. Anterior cephalic aspect of female H. labori$o s a$, with mouthparts extended in typical floral probing position (documented photographically). Body surfaces that accumulate considerable Vaccinium pollen are stippled (documented with $>30$ collected specimens and 18 field photographs of foragers). The border of dashed lines represents the anterior tip of a $V$. ashei corolla, drawn to scale, and a representative placement of the stigma (s) against the bee's head (redrawn from photograph). Note the slight exsertion of the pistil beyond the recurved petal tips.

Bombus spp. sonicate or buzz (sensu Buchmann 1983) the flowers. The group of four polylectic Bombus spp. (Cane 1987) that foraged concurrently at our sites produced as many multiple buzzes per floral visit as does $H$. laboriosa $(P>0.5)$ (Table 1). Significant differences in the number of buzzes per flower were detected by nested ANOVA among individual foraging bouts $(P<0.0001)$ but not between the two genera $(P>0.5)$.

As she sonicates, a female $H$. laboriosa always thrusts her proboscis into the pendant flower (Fig. 2). As a result, her mouthparts, labrum and/or clypeus (depending upon corollar depth), plug the constricted orifice of the Vaccinium corolla. The labrum most commonly accumulated noticeable pollen, as evidenced in our photographs $(n=18)$, pinned specimens $(n=49)$, and live individuals $(n>300)$ (Fig. 3). The bee grooms pollen from these lower facial regions using its forelegs. As the bee probes, these regions butt against the flower's sticky stigmatic surfaces (Fig. 3). Therefore, these lower facial regions constitute the primary "safe site" for stigmatic pickup of Vaccinium pollen.

Foraging Rates. Species-specific differences were detected among the mean floral handling rates of

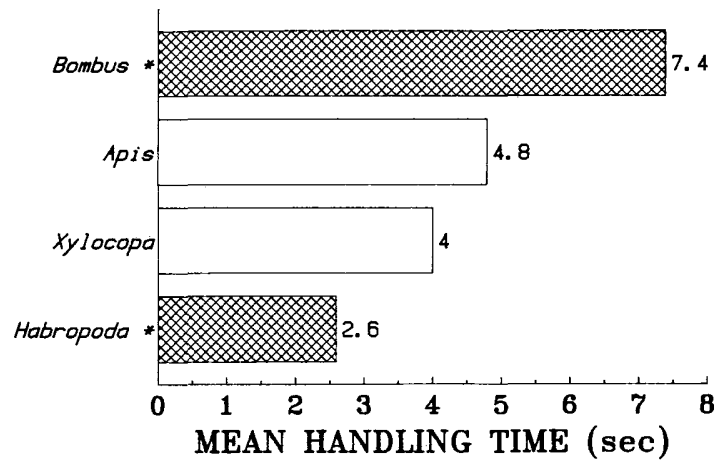

Fig. 4. Mean floral handling durations of pollenforaging female $H$. laboriosa and Bombus spp. (four pooled), and nectarivorous honeybees and $X$. virginica, at flowers of $V$. ashei. Sample of 400 visits by 34 bees; * denotes significant difference at $P<0.05$. Clear bar, nectarivores; cross-hatched bar, pollen foragers.

pollen-foraging female $H$. laboriosa and Bombus (four spp. pooled) and nectarivorous honey bees and $X$. virginica, all at $V$. ashei $(P=0.014)$. Rates of floral handling also varied significantly among the foraging sequences of different individuals $(P<$ $0.0001)$. An a posteriori comparison of the pollenforaging taxa indicated that $H$. laboriosa worked $V$. ashei flowers significantly faster $(\bar{x}=2.6 \mathrm{~s}, 11$ bees, 142 flowers) than the four pooled pollen-foraging Bombus species ( $\bar{x}=7.4 \mathrm{~s}, 9$ bees, 107 flowers) (Fig. 4). Floral handling durations positively correlated with the number of buzzes delivered to a flower by the pollen-foraging bees $\left(r=0.68, t_{s}=\right.$ $14.3 \gg t_{0.001(237)}=3.3$ ), perhaps reflecting the bee's perception of and response to harvestable pollen (Table 1).

The range in mean floral handling rates among individual Bombus foragers is more than 5 times that of female $H$. laboriosa at $V$. ashei (Fig. 5). Pollen-foraging $H$. laboriosa females were significantly less variable from individual to individual in mean floral handling rate on $V$. ashei than the four coforaging Bombus spp. (Fig. 5). Using logtransformed data to calculate the ratio of their calculated mean variances $(0.049$ Bombus $/ 0.012$ Habropoda $=3.94$ ), their species-specific mean variances were significantly different $(P<0.025)$ when compared to the $F$ distribution $\left(F_{9,11, P=0.05}=\right.$ 3.07) (Lewontin 1966), demonstrating greater uniformity in floral handling times by individual $H$. laboriosa relative to individual bumble bee females.

Table 1. Numbers of buzzes delivered to $V$. ashei flowers by pollen-foraging female Bombus (four species pooled) and $H$. laboriosa

\begin{tabular}{lrrrrrr}
\hline \hline Visitor & $\begin{array}{c}\text { No. } \\
\text { bees }\end{array}$ & $\begin{array}{r}\text { No. } \\
\text { flow- } \\
\text { ers }\end{array}$ & $\begin{array}{c}\text { Mean } \\
\text { buzzes }\end{array}$ & SD & $\begin{array}{c}\text { Me- } \\
\text { dian }\end{array}$ & Range \\
\hline $\begin{array}{l}\text { Habropoda } \\
\text { laboriosa }\end{array}$ & 11 & 142 & 5.7 & 3.7 & 4 & $0-19$ \\
$\begin{array}{l}\text { Bombus spp. } \\
\text { Bombra }\end{array}$ & 8 & 97 & 5.2 & 3.3 & 5 & $0-16$ \\
\hline
\end{tabular}




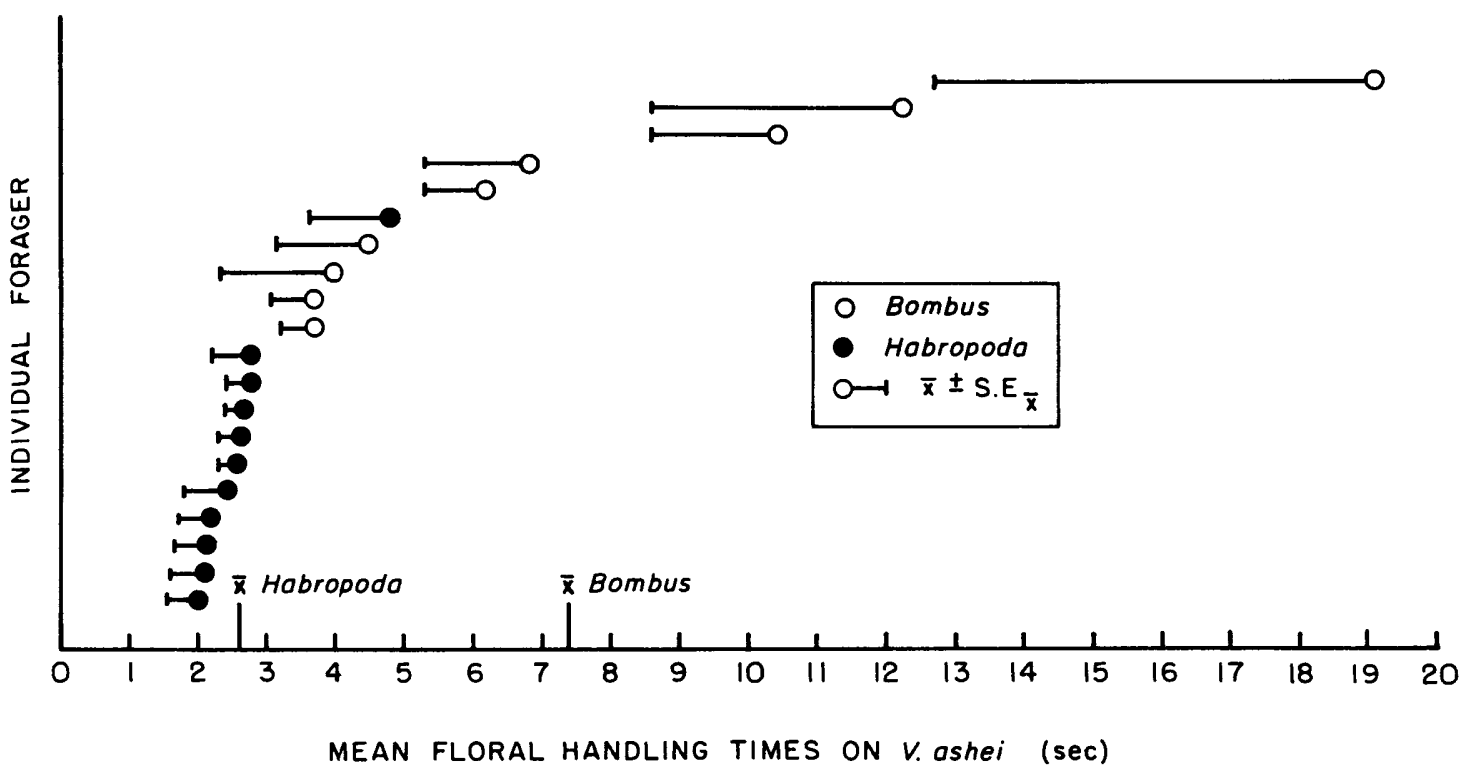

Fig. 5. Mean floral handling durations of 11 female H. laboriosa (filled circles) and nine Bombus (four species) (open circles) as they concurrently foraged for pollen and nectar at $V$. ashei (249 floral visits). Bars represent one standard error of each individual's mean. The two species' means are shown on the $x$ axis.

The mean interfloral travel durations (time expended traveling between flowers) by these same individual Habropoda, Bombus, Apis, and Xylocopa bees showed significant differences among individuals $(P<0.0001)$ but not between species when individual mean square was the error term $P=0.257)$ (Fig. 6). All these interfloral flights were to flowers on the same plant. Intrinsic variation in interfloral travel time among individual pollen-foraging Bombus spp. and $H$. laboriosa were insignificant $(P>0.3)$.

During our net exclusion experiments, female H. laboriosa, Bombus, and Xylocopa visited previously bagged, virgin flowers more slowly than they concurrently visited open inflorescences (Fig. 7 ). Twenty female $H$. laboriosa visited virgin flowers $>5$ times slower $(\bar{x}=9.3 \pm 2.3 \mathrm{SD}$ s per flower, 143 flowers) than 13 conspecific bees concurrently visiting neighboring open inflorescences $(\bar{x}=1.8 \pm$ $0.4 \mathrm{~s}$ per flower, 93 flowers). Seven bumble bees visited 81 virgin flowers $7.3 \pm 2.6 \mathrm{~s}$ per flower, which was 4.5 times slower than visits to open inflorescences $(\bar{x}=1.6 \pm 0.3 \mathrm{~s}$ per flower, $n=4$ bees, 46 flowers). The mean visitation rate of five nectarivorous $X$. virginica to virgin flowers was only a quarter of that to open flowers $(\bar{x}=10.9$ versus $2.9 \mathrm{~s}$ ).

Relative Abundances at Cultivated $\boldsymbol{V}$. ashei. Censuses taken during 1985 and 1986 at seven cultivated $V$. ashei sites in Alabama, Florida, and Georgia indicated great variations in the absolute densities of $H$. laboriosa and in this species' relative representation in the guild of $V$. ashei visitors at any one site.

At the $V$. ashei planting south of Auburn, $H$. laboriosa was consistently abundant throughout the flowering season (Fig. 8A), despite $>100$ adjoining honey bee colonies. Early in the season, when $1 \%$ of the flower buds had opened $(n=745)$, there was an average of seven female $H$. laboriosa per 10 bushes. Over half of these females bore scopal pollen loads (compared with a total of two bumble bees and two honey bees with pollen loads at 25 sampled bushes). Later in the season, when there were $45 \%$ flower buds, $34 \%$ open flowers, and $21 \%$ senescent flowers $(n=592)$, a census at 25 bushes revealed that 65 of the 66 bees sonicating flowers were female $H$. laboriosa ( 1 sonicating bumble bee of 22 observed, 0 of 38 honey bees, $24 \mathrm{H}$. laboriosa taking nectar only, 150 bees total). On the next day, an hour later (1200 hours), the only bees son-

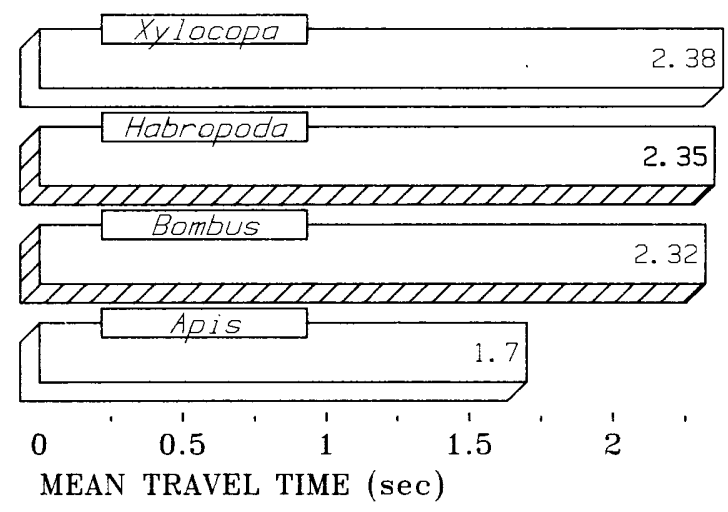

Fig. 6. Mean interfloral travel durations of the same recorded foraging bouts of the 34 bees shown in Fig. 4 ( $n=397$ "moves" by the same 11 H. laboriosa, 9 Bombus, 10 honey bees, and $4 X$. virginica). Slashed bars, pollen foragers; clear bars, nectarivores. 


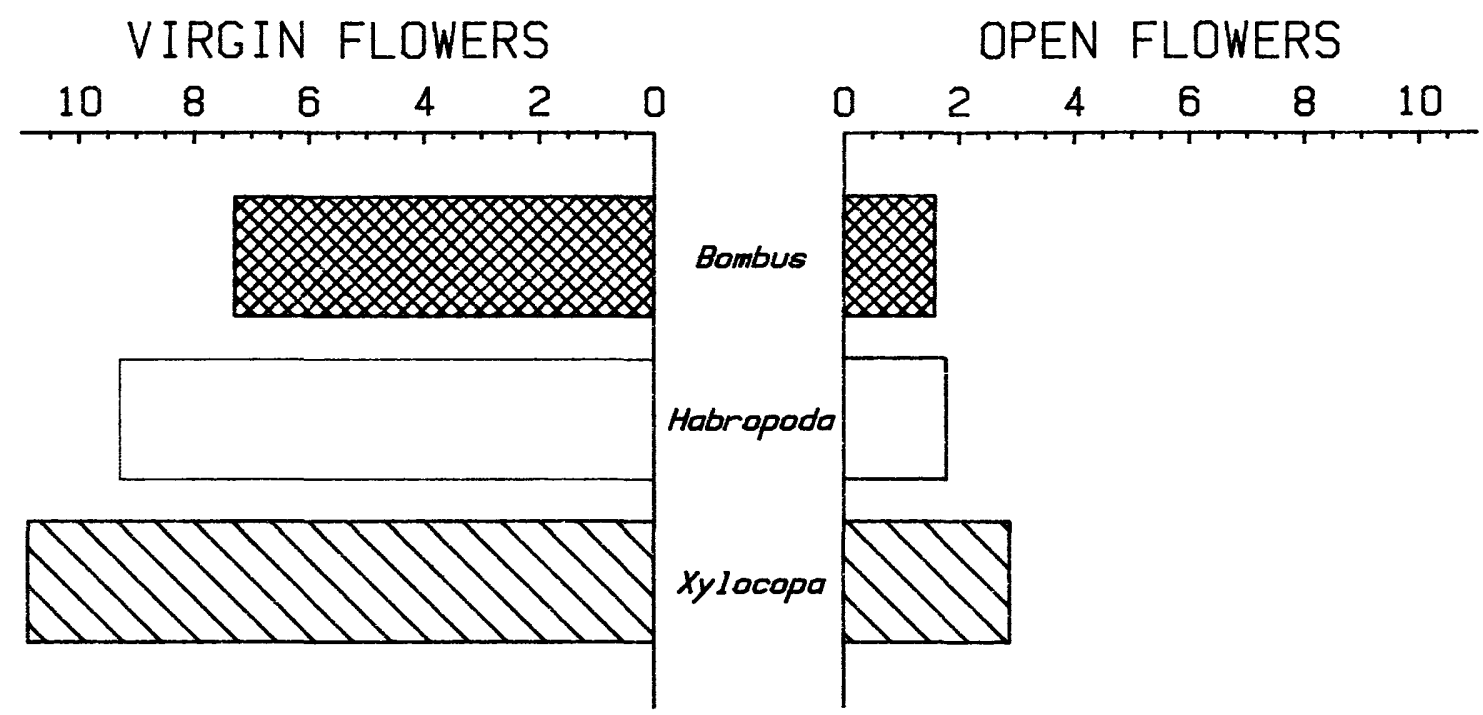

Fig. 7. Prolongation of floral visitation rates of bees at $V$. ashei in response to accumulated floral resources. Durations are the sum of handling time and interfloral travel time. Visitation rates are significantly different $(P<$ 0.05 ) between open and virgin flowers in pairwise comparisons.

icating these $25 \mathrm{~V}$. ashei were $H$. laboriosa $(n=55$ of 102 total foraging $H$. laboriosa), although 128 A. mellifera, 21 Bombus spp., and $10 \mathrm{X}$. virginica were also tallied ( $n=261$ total bees) as they foraged for nectar. At the Auburn campus site, the relative proportions of buzzing bees were similar to the above, with $H$. laboriosa predominating, but here honey bees were virtually absent.

At the Bolingbroke and Fort Valley sites in Georgia (approximately $50 \mathrm{~km}$ apart) during 24-25 March, the proportional abundances of $\mathrm{H}$. laboriosa were radically different (Fig. $8 \mathrm{~B}$ and $\mathrm{C}$ ). At the Bolingbroke planting, which had six peripheral honey bee colonies, we counted 1,676 honey bees ( $0.8 \%$ with pollen loads) and only four male $H$. laboriosa, seven Bombus spp., and $44 X$. virginica (one with a pollen load) between 0900 and 1700 hours at 33 plants of each of the four cultivars 'Climax,' 'Delite,' 'Tifblue,' and 'Woodard.' We counted as many as 247 honey bees at 33 plants by 1400 hours and an overall daily average of 1.4 honey bees per bush. These censuses were taken early in the flowering phenology at this site $(74 \%$ bud, $16 \%$ open flowers, $10 \%$ senescent, $n=1,157$ ), but $H$. laboriosa continued to be rare at this planting.

Conversely, at the Fort Valley site, $H$. laboriosa females were abundant and honey bees were virtually absent at $V$. ashei (although honey bees frequented nearby Prunus umbellata) (Fig. 8C). From 0930 to 1730 hours at the cultivars 'Tifblue' and 'Woodard' (intergrown plants), a total of 306 bees was counted, of which $96 \%$ were $H$. laboriosa (39 males, 186 pollen-collecting females, 67 nectarivorous females), 11 were Bombus spp., 3 were $X$. virginica, and none was honey bee. Similar proportions were noted at planted V. ashei near Mon- ticello, Fla. Flowering phenology at Fort Valley was similar to that at Bolingbroke $(78 \%$ bud, $15 \%$ open flowers, $7 \%$ senescent, $n=673$ ), as were the daily maximal temperatures $\left(19-28^{\circ} \mathrm{C}\right)$.

\section{Discussion}

Oligolecty in bees is a species-specific predilection for harvesting pollen from a group of related plant species to the general exclusion of other flowers, except in the absence of local host pollen (Linsley 1958). Some expected proximal correlates in the foraging ecology of an oligolectic bee species, relative to competing polyleges, include seasonal and daily matching of female foraging activity and host plant flowering and anthesis, consistent predominance of host pollen in scopal pollen loads, disproportionate oligolege abundance at the host plant (narrow foraging niche), and greater efficiency in resource extraction per unit time at the host plant (Cane \& Eickwort in press). If the beeflower association has mutualistic aspects, then we might also expect morphological correlates of bee and flower. We address these characteristics in turn for $H$. laboriosa and its nearctic congeners.

As a species, $H$. laboriosa appears to be vernally univoltine, like $H$. miserabilis in Oregon (Stephen \& Torchio 1961, Gordon 1984), H. pallida (Bohart et al. 1972) and H. depressa (Fowler 1899) in California, and H. birkmanni in Texas (Cockerell 1934), with no bimodality of adult activity indicated in available collections, even for the winter populations of the Florida peninsula. We observed that the early vernal emergence of adults in the southeastern United States (at least north of Florida) corresponds well with the blooming of most but not all Vaccinium species (e.g., not V. arboreum 

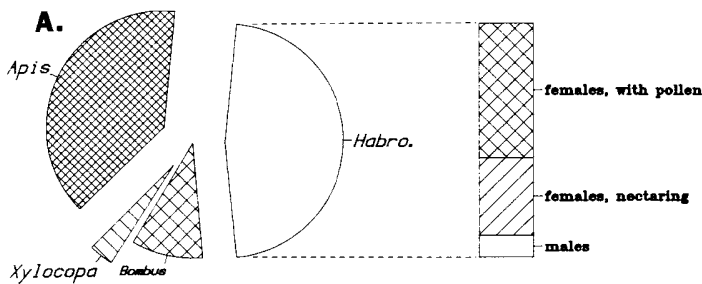

HABROPODA FORAGING

Fig. 8A. Composition of the bee foraging guild at planted V. ashei near Auburn, Ala., summarized from censuses at the cultivars 'Climax,' 'Delite,' and 'Tifblue. Censuses ( 447 bees) taken during three walking scan samples at 25 plants each.

Marshall or V. stamineum). This 3-5-wk phenological window is a small part of the local 30-35$w \mathrm{k}$ growing season, which limits their menu of available flowers to about $5-10 \%$ of the total southeastern flora (Radford et al. 1968). Vernal univoltinism is adaptive for H. laboriosa foraging at Vaccinium, but it is also common to other studied species of Habropoda.

Diurnal synchrony of $V$. ashei anthesis and foraging by $H$. laboriosa are not notable, as the flowers are available for most of the day (and persist 3-5 d [J.H.C., unpublished data]). Female $\boldsymbol{H}$. laboriosa can be seen foraging for both nectar and pollen for much of the day in suitable weather, not unlike some of the polyleges in its pollen-foraging guild. Diurnal synchrony seems to be a minor constraint for a Vaccinium visitor, except for probable floral resource depletion as the day progresses (evidenced, perhaps, by the protracted visits to virgin flowers in our exclusion experiment) (Fig. 7). Prolonged foraging days are also reported for $\mathrm{H}$. miserabilis (Stephen \& Torchio 1961) and $H$. pallida (Bohart et al. 1972).

Taxonomically homogeneous scopal pollen loads, dominated by Vaccinium pollen, reflect the rarity of observed visits by female $H$. laboriosa to nonVaccinium flowers, especially for pollen (Fig. 1). Although these are less pure than the pollen loads

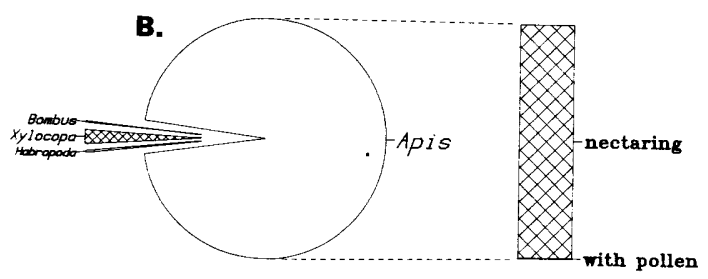

APIS FORAGING

Fig. 8B. Composition of the bee foraging guild at planted V. ashei near Bolingbroke, Ga., summarized from nine hourly censuses on 24 and 25 March. Censuses (1,831 bees) made from 36 walking scan samples at 33 plants each.

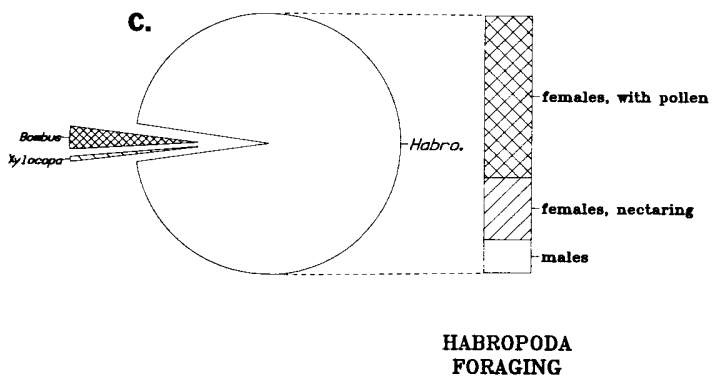

Fig. 8C. Composition of the bee foraging guild at planted V. ashei near Fort Valley, Ga., on 26 and 27 March. Data is a compilation of nine hourly censuses (306 bees) made from 18 walking scan samples at 33 plants each.

reported from Melitta americana (Smith), another Vaccinium oligolege (of V. stamineum) (Cane et al. 1985), the H. laboriosa loads are certainly more purely Vaccinium than those sampled from the honey bee colonies at Bolingbroke. Some apparently passive contamination, as by Pinus spp. pollen, is also evident.

The occasional use of redbud for pollen by female $H$. laboriosa may reflect a generic floral preference, as H. birkmanni (Cockerell 1934), H. miserabilis (Stephen \& Torchio 1961, Gordon 1984), and $H$. pallida (Bohart et al. 1972) also gather pollen from papilionaceous legumes (Lupinus spp.). Some museum specimens of $H$. laboriosa collected in Florida were also collected at lupine and bore its pollen.

Oak pollen, which is anemophilous, is also collected by $H$. depressa (Fowler 1899). The vernal oligolege, Andrena erythronii Robertson, substitutes oak pollen only when its pollen host is no longer available (Michener \& Rettenmeyer 1956). Late-season use of oak pollen by $H$. laboriosa may be similarly explained.

The only abundant solitary bee to gather pollen regularly at $V$. ashei at our sites is $H$. laboriosa (Fig. $8 \mathrm{~A}-\mathrm{C})$. No other Habropoda species is reported to sonicate flowers. In the absence of hived honey bees, we observed that $H$. laboriosa was generally the abundant bee at flowering $V$. ashei (and, by casual observation, at nearby $V$. corymbosum), both daily and annually (Fig. 8C). Even in the presence of honey bees and bumblebees, $H$. laboriosa can be the predominant pollen collector at these two Vaccinium spp. as evidenced by its floral sonication and visible pollen loads (Fig. 8A). Generally, H. laboriosa was not seen gathering pollen at coflowering genera other than Vaccinium (e.g., Prunus), although these were used by polyleges in the $V$. ashei foraging guild.

Perhaps because of the proximity of its nesting sites, $H$. laboriosa is patchily abundant, however, as evidenced by its rarity at the Bolingbroke site and predominance at the nearby Fort Valley site (Fig. $8 \mathrm{~B}$ and C). The disparity in species abundances between the Fort Valley and Bolingbroke 
sites does not reflect phenological, climatic, or macrogeographic differences but perhaps does reflect the proximity of nesting sites. In the absence of $H$. laboriosa, however, no other bee abundantly occupies its pollen-foraging niche at either $V$. ashei or $V$. corymbosum at our sites.

The subcephalic safe site of both sexes of $H$. laboriosa, where stigmatic surfaces encounter ungroomed conspecific pollen (Fig. 3), is morphologically unusual for bees (reviewed in Cane \& Eickwort in press). Studies of bees typically find safe sites in the ventral cervical fossa, atop the thoracic dorsum, ventrally between the coxae, or beneath the abdomen (e.g., Beattie 1971, 1972, Green \& Bohart 1975). The subcephalic safe site reflects the size of $H$. laboriosa, its tongue length, use of sonication to release pollen, positioning on the $\mathrm{Vac}$ cinium flower (Fig. 2), and the urceolate corolla and connivant, poricidally dehiscent anthers of the flower.

Female $H$. laboriosa forage more rapidly for $V$. ashei pollen than do the competing polylectic species of Bombus (Fig. 4). Superior floral handling speed of an oligolege over that of a coforaging polylege has previously been shown only for oligolectic Hoplitis anthocopoides (Schenk) versus polylectic Megachile species at Echium vulgare L. (Strickler 1979). Rapid floral handling times are known for other medium- to large-sized oligoleges that buzz-pollinate, such as Melitta americana (Sinith) at V. stamineum (Cane et al. 1985) and Ptiloglossa arizonensis Timberlake at Solanum elaeagnifolium Cavanilles (J.H.C. \& S. L. Buchmann, unpublished data). Interestingly, H. laboriosa fails to travel more quickly between $V$. ashei flowers than do competing polylectic bees (Fig. 6). In contrast, Strickler (1979) reported H. anthocopoides to move $35 \%$ faster between flowers than Megachile spp. at E. vulgare. Rapid pollen-nectar foraging rates of $H$. laboriosa (10-20 Vaccinium flowers per min) are exceptional among oligolectic solitary bees (Cane \& Eickwort in press), and may enhance its pollination efficacy.

The lesser variance in floral handling rate among individual $H$. laboriosa compared with Bombus spp. at $V$. ashei (Fig. 5) may result from evolutionary or behavioral phenomena or both. If foraging rate is indeed heritable (requiring testing of naive bees), then lessened variance would be the predicted outcome of selection against slower foragers (who might provision fewer nest cells), thereby speeding the species' mean handling time in subsequent generations while leaving a more leptokurtic distribution of individual handling times. If the ultimate explanation is behavioral, then the slower handling times and greater variance among polyletic bumblebees may reflect their greater range of experience with Vaccinium, from naive to expert, relative to more consistently experienced $H$. laboriosa females. Considering the rapid learning curves for naive bumblebees at monkshood (Heinrich 1976), however, we favor the evolutionary explanation. Whether attributable to ancestry or selection, the uniformly rapid floral handling rates, vernal univoltinism, and the Vaccinium pollen preferences of $H$. laboriosa all point to its oligolectic specialization at Vaccinium species in the southeastern United States.

\section{Acknowledgment}

We thank Ann Amis, Linda Kervin, and Gwen Snyder for field and laboratory assistance, Dan Horton and Jeff Turner for field help, and the generosity of growers, particularly Millie Stewart and Guelda Hay, Frank Randle, and Harold Reade. Constructive reviews were provided by Robert Brooks, Phil Torchio, Michael Gaylor, Paul Lyrene, and Patricia Cobb. The work was partially supported by the Auburn University Grant-in-Aid Program. Publication assistance was provided by the USDA Fruit and Tree Nut Laboratories. Alabama Agricultural Experiment Station Journal Series No. 17-871209.

\section{References Cited}

Beattie, A. J. 1971. Pollination mechanisms in Viola. New Phytol. 70: 343-360.

1972. The pollination ecology of Viola. 2: pollen loads of insect-visitors. Watsonia 9: 13-25.

Bohart, G. E., P. F. Torchio, Y. Maeta \& R. W. Rust. 1972. Notes on the biology of Emphoropsis pallida Timberlake. J. Kans. Entomol. Soc. 45: 381-392.

Buchmann, S. L. 1983. Buzz pollination in angiosperms, pp. 73-113. In C. E. Jones \& R. J. Little [eds.], Handbook of experimental pollination biology. Van Nostrand Reinhold, New York.

Cane, J. H. 1987. The importance of native bees to rabbiteye blueberry production, pp. 42-49. In Proceedings for the 3rd Biennial Southeast Blueberry Conference and Trade Show, Tifton, $\mathrm{Ga}$

Cane, J. H. \& G. C. Eickwort. In press. Oligolecty, oligophily, and the role of specialization in bee-flower coevolution. In S. Buchmann [ed.], Pollination efficiency, University of Arizona Press.

Cane, J. H., G. C. Eickwort, F. R. Wesley \& J. Spielholz. 1985. Pollination ecology of Vaccinium stamineum (Ericaceae: Vaccinioideae). Am. J. Bot. 72: 135-142.

Cockerell, T. D. A. 1934. New and little-known western bees. American Museum Novitates 372.

Fowler, C. 1899. The Habropoda and Diadasia of California. Can. Entomol. 31: 283-286.

Garcia, L. E. 1981. Attractiveness of rabbiteye blueberry cultivars to pollinating insects and the effects of honey bees and gibberellic acid on fruit set and development. M.S. thesis, North Carolina State University, Raleigh.

Gordon, D. M. 1984. Ecology of bees from coastal dunes, Humboldt County, California. M.A. thesis, Humboldt State University, Humboldt, Calif.

Green, T. W. \& G. E. Bohart. 1975. The pollination ecology of Astragalus cibarius and Astragalus utahensis (Leguminosae). Am. J. Bot. 62: 379-386.

Heinrich, B. 1976. Foraging specializations of individual bumblebees. Ecol. Monogr. 46: 105-128

Hurd, P. D. \& E. G. Linsley. 1975. The principal Larrea bees of the southwestern United States ( $\mathrm{Hy}-$ menoptera: Apoidea). Smithsonian Contributions to Zoology 193. 
Krombein, K. V., P. D. Hurd, Jr., D. R. Smith \& B. D. Burks [eds.]. 1979. Catalog of Hymenoptera in America north of Mexico, vol. 2. Smithsonian Institution, Washington.

Lewontin, R. C. 1966. On the measurement of relative variability. Syst. Zool. 15: 141-142.

Linsley, E. G. 1958. The ecology of solitary bees. Hilgardia 27: 543-599.

Linsley, E. G., J. W. MacSwain \& P. H. Raven. 1963. Comparative behavior of bees and Onagraceae. I. Oenothera bees of the Colorado Desert. II. Oenothera bees of the Great Basin. University of California Publications in Entomology 33.

Michener, C. D. \& C. W. Rettenmeyer. 1956. The ethology of Andrena erythronii with comparative data on other species (Hymenoptera, Andrenidae). Univ. Kans. Sci. Bull. 37: 645-684.

Mitchell, T. B. 1962. Bees of the eastern United States, vol. II. North Carolina Agricultural Experiment Station Technical Bulletin 141.
Ornduff, R. 1970. The systematics and breeding system of Gelsemium (Loganiaceae). J. Arnold Arbor. 51: $1-17$.

Radford, A. E., H. E. Ahles \& C. R. Bell. 1968. Manual of the vascular flora of the Carolinas. University of North Carolina, Chapel Hill.

SAS Institute. 1985. SAS user's guide: statistics, version 5 ed. SAS Institute Inc., Cary, N.C.

Stephen, W. P. \& P. F. Torchio. 1961. Biological observations on Emphoropsis miserabilis (Cresson) with comparative notes on other anthophorids. Ann. Entomol. Soc. Am. 54: 687-692.

Strickler, K. 1979. Specialization and foraging efficiency of solitary bees. Ecology 60: 998-1009.

Uno, G. E. 1982. The influence of pollinators on the breeding system of Iris douglasiana. Am. Midl. Nat. 108: $149-158$

Received for publication 7 May 1987; accepted 25 November 1987. 